\title{
$\begin{array}{lllllllllllllllll}\mathbf{R} & \mathbf{O} & \mathbf{Z} & \mathbf{P} & \mathbf{R} & \mathbf{A} & \mathbf{W} & \mathbf{Y} & \mathbf{I} & \mathbf{A} & \mathbf{R} & \mathbf{T} & \mathbf{Y} & \mathbf{K} & \mathbf{U} & \mathbf{L} & \mathbf{Y}\end{array}$
}

Prawo Kanoniczne 57 (2014) nr 1

KS. GINTER DZIERŻON

Wydział Prawa Kanonicznego

Uniwersytetu Kardynała Stefana Wyszyńskiego w Warszawie

\section{EWOLUCJA ZNACZENIA TERMINU „OSOBA MORALNA" W KANONICZNYM PORZĄDKU PRAWNYM}

Treść: Wstęp. - 1. Pojęcie „osoba moralna” w Kodeksie z 1917 r. - 1.1. Geneza wprowadzenia terminu „osoba moralna” do systemu kanonicznego. - 1.2. Teorie osoby prawnej. -1.3 . Osoba moralna a osoba prawna. -2 . Problem osoby moralnej w pracach nad rewizją Kodeksu z 1917 r. - 3. Pojęcie „osoba moralna” w Kodeksie z 1983 r. - 3.1. Status osobowości moralnej. - 3.2. Specyfika podmiotowości Kościoła katolickiego i Stolicy Apostolskiej. - Zakończenie.

\section{Wstęp}

W doktrynie kanonistycznej sporo kontrowersji wiązało się z celowością wprowadzenia terminu „osoba moralna” do obiegu normatywnego związanego z osobowością prawną. W Kodeksie pio - benedyktyńskim w tym obszarze pojęcie to było kategorią dominującą; nazwa „osoba prawna” natomiast, co obecnie należałoby uznać za pewne kuriozum, znalazła się tylko w trzech regulacjach (kan. 687, 1489 § 1, $1494 \S 2 \mathrm{KPK})^{1}$.

W obowiązującej kodyfikacji termin „osoba moralna” występuje wyłącznie w kan. $113 \S 1 \mathrm{KPK}$; terminem przeważającym zaś jest pojęcie „osoba prawna”. W tym kontekście rodzi się zatem zasadnicze pytanie: jakie racje zadecydowały o zmianie podejścia prawodawcy

${ }^{1}$ Por. G. Lo Castro, Comento al can. 113 CIC, w: Comentario exegético al Código de Derecho Canónico, red. A. Marzoa, J. Miras, R. Rodríguez - Ocaña, t. 1, Pamplona 1996, s. 774. 
kościelnego w tej kwestii? Znalezienie odpowiedzi na tę wątpliwość stanie się przedmiotem zainteresowania w niniejszym opracowaniu.

\section{Pojęcie „osoba moralna” w Kodeksie z 1917 r.}

Jak już nadmieniono, w Kodeksie pio - benedyktyńskim kluczową kategorią pojęciową była kategoria osoby moralnej². Termin „osoba moralna" występował w kilku regulacjach, to znaczy, w kan. 99-103 i w kan. 106 KPK. Na użytek tego opracowania należałoby przytoczyć treść kan. 99 i 100 § 1 KPK. Otóż w kan. 99 KPK prawodawca stanowił, że w Kościele oprócz osób fizycznych istnieją także osoby moralne; w kan. 100 § 1 KPK natomiast stwierdził on, że Kościół katolicki i Stolica Apostolska są osobami moralnymi z ustanowienia Bożego.

\subsection{Geneza wprowadzenia terminu „osoba moralna” do systemu kanonicznego}

Termin „osoba moralna” nie jest pojęciem wypracowanym w kanonistyce. W literaturze wskazuje się, iż został on zaczerpnięty z cywilistycznej francuskiej doktryny prawa naturalnego ${ }^{3}$. P. Lombardía uznał tego typu recepcję za zaskakującą ${ }^{4}$.

A. Gautier twierdzi, że po raz pierwszy posłużył się nim przedstawiciel iusnaturalizmu S. Putendorf ${ }^{5}$; A. Heine z kolei jako pierwszy odniósł to pojęcie, w opozycji do osoby fizycznej, do osobowości prawnej osoby moralnej ${ }^{6}$.

W podręcznikach przedkodeksowych zasadność operowania pojęciem „osoba moralna” thumaczono racjami filozoficznymi oraz powodami wynikającymi z doktryny prawa publicznego. Filozoficznie osobę

2 Por. F. Wernz, P. Vidal, Ius canonicum, t. 2, Romae 1923, s. 26.

3 Por. A. Gautier, Le persone giuridiche nel Codice del 1983, Angelicum 69(1992), s. 108; W. Aymans, K. Mörsdorf, Kanonisches Recht, t. 1, Padeborn - München Wien - Zürich 1991, s. 308; S. Bueno Salinas, Persona moral, w: Diccionario general de Derecho Canónico, red. J. Otaduy, A. Viana, J. Sedano, t. 6, Pamplona 2012, s. 191.

${ }^{4}$ Por. P. Lombardía, Lecciones de derecho canonico, Madrid 2004, s. 140.

5 Szerzej na temat tej postaci zob. A. Padoa Schioppa, Storia del diritto in Europa, Bologna 2007, s. 337-340.

6 A. Gautier, Le persone giuridiche, dz. cyt., s. 107. 
moralną definiowano jako zbiór osób fizycznych powiązanych węzłem moralnym. Na gruncie prawa publicznego natomiast odwoływano się do kategorii społeczności, pojmowanej jako zjednoczenie wielu osób realizujących misję dla dobra wspólnego (F. Cavagnis, G. Waffelaert) ${ }^{7}$. L. Hunguenin w swej ,.Expositio methodica Iuris Canonici” przekonywał, że wprowadzenie tego terminu wynikało z dwóch zasadniczych powodów, mianowicie, z jednej strony funkcjonowanie osób moralnych w kanonicznym porządku prawnym wiąże się z realizacją celów Kościoła, z drugiej zaś wynika z pryncypium, w myśl którego erekcja osób moralnych, ich kontrola i protekcja należy do autorytetu kościelnego ${ }^{8}$.

Należy dodać, iż treść kanonów odnoszących się do osobowości prawnej została także przejęta $\mathrm{z}$ ustawodawstwa cywilnego. Według kanonistów, regulacje skodyfikowane w Księdze II „De personis”, a także sam układ Księgi zostały przejęte z XIX w. niemieckiego prawa prywatnego, a w sposób szczególny z Kodeksu z 1900 r. ${ }^{9}$. Z kolei G. Lo Castro w swych badaniach nad procesem kodyfikacji pierwszego Kodeksu Prawa Kanonicznego wykazał, iż na ostateczny kształt regulacji Kodeksu z 1917 r. wywarli znaczący wpływ tacy konsultorzy, jak C. Lombardi i A. Sili ${ }^{10}$.

\subsection{Teorie osoby prawnej}

W literaturze wskazuje się, iż w znanym zbiorze źródeł „CIC Fontes" ${ }^{11}$ nie znalazł się ani jeden tekst, który odnosiłby się do kwestii oso-

7 Por. G. Lo Castro, Personalità morale e soggettività nel diritto canonico, Milano 1974, s. 16-17.

${ }^{8}$ Por. L. Hunguenin, Expositio methodica Iuris Canonici, t. 1, Parisii 1877, t. 1, s. 368: „Praeter singulas laicorum personas Ecclesia in sinu suo etiam continet personas morales, qua finem specialem prae se ferunt, et subsistentiam per se stantem quodammodo habent, ita ut fini supremo Ecclesiae quoad omnia respondere debeant".

9 A. Gautier, Le persone giuridiche, dz. cyt., s. 106.

${ }^{10}$ G. Lo Castro, Personalità morale, dz. cyt., s. 20-38. Vota tych konsultorów zostały zamieszczone w aneksie tej monografii. Zob. Appendice di documenti, s. 230-231.

${ }^{11}$ Por. Codicis iuris canonici fontes, red. P. Gasparri, I. Serédi, t. 1-10, Roma 19261939. 
by prawnej. W doktrynie obrano natomiast inny kierunek; zmierzano bowiem do wypracowania teorii osoby prawnej ${ }^{12}$. W myśl doktryny, problem konceptu osoby prawnej (moralnej) jest niezwykle istotny z punktu widzenia technik jurydycznych ${ }^{13}$.

Najstarszą, funkcjonującą również obecnie teorią jest teoria fikcji prawnej, powstała już w epoce kanonistyki klasycznej (Sinibaldus de Fieschi) ${ }^{14}$. W tym ujęciu, podmiotowość osoby prawnej przyrównuje się na zasadzie analogii do podmiotowości osoby fizycznej. Mechanizm jej funkcjonowania polega na przypisaniu pewnych cech komuś, kto tych cech nie posiada ${ }^{15}$.

G. Lo Castro twierdzi, że to w kanonistyce przedkodeksowej inspirowanej cywilistycznymi teoriami osoby prawnej wypracowano kategorię osoby moralnej w znaczeniu współczesnym (F. Cavagnis). Ujmowano bowiem tę kategorię osób w znaczeniu funkcjonalnym, wiążąc ją z pojęciem substancji. Przedstawiciele tego nurtu utrzymywali, że zasadniczą funkcją tego typu osobowości jest tworzenie nowych substancji, w znaczeniu nowych podmiotów prawa ${ }^{16}$. Źródeł tej teorii upatrywano w prawie germańskim, uznającym zdolność szczepu do bycia podmiotem prawa (O. Gierke) ${ }^{17}$.

${ }^{12}$ Por. S. Bueno Salinas, La noción de persona jurídica en le derecho canónico, Barcelona 1985, s. 121.

${ }^{13}$ Tamże, s. 125: „Reproduciendo las palabras textuales del gran maestro italiano Ferrara, se puede afirmar que «el concepto de personalidad es uno de los problemas más graves y delicados de la técnica jurídica, que está relacionado y guarda un intimo vinculo con la idea de Derecho subjetivo, por lo que se originan una serie de controversias y de dudas que hacen cada vez más dificil su solución»".

${ }^{14}$ Szerzej na ten temat zob. S. Panizo Orallo, Persona jurídica y ficción, Pamplona 1975, s. 147-268.

${ }^{15}$ S. Bueno Salinas, La noción de persona jurídica, dz. cyt., s. 126.

${ }^{16}$ G. Lo CAstro, Personalità morale, dz. cyt., s. 46-51: „La funzione della personalità, in tale contesto concettuale, altra non poteva essere, allora, che quella di creare nuove sostanze, vale a dire nuovi soggetti di diritto, dotati di capacità generale, potenzialmente idonei a riassumere in sè tutte le situazioni giuridiche, svolgenti come tali, a loro volta, una funzione centrale nell' ordinamento, che per essi è posto e per mezzo di essi si sviluppa".

${ }^{17}$ Por. W. Aymans, Kollegium und kollegiarer Akt in kanonischen Recht. Eine rechtsbegriffliche Untersuchung inbesondere aufgrund des Codex Iuris Canonici, München 
G. Michels z kolei utrzymywał, iż prawodawca w pierwszej kodyfikacji konsekrował teorię abstraktu, opierającą swą konstrukcję na założeniach metafizycznych. W myśl przyjętych założeń, osoba prawna nie jest sumą osób lub rzeczy, lecz bytem abstrakcyjnym ${ }^{18}$.

W jeszcze inny sposób fenomen osoby prawnej tłumaczył F. Ferrara $\mathrm{w}$ teorii koncesji, zwanej też teorią formy prawnej. Twierdził on, że osoba moralna nie mogłaby być podmiotem prawa, jeśli osobowość nie zostałaby jej nadana przez kompetentną władzę ${ }^{19}$.

$\mathrm{Z}$ badań nad dokonaniami kanonistyki uprawianej pod rządami Kodeksu z 1917 r. przeprowadzonych przez S. Bueno Salinasa wynika, iż ówcześni komentatorzy podchodzili do tych teorii z pozycji uprzywilejowanej, aprobując jedną z nich. Najczęściej jednak opowiadali się za klasyczną teorią fikcji prawnejej.

\subsection{Osoba moralna a osoba prawna}

$\mathrm{Z}$ analiz semantycznych regulacji Kodeksu pio - benedyktyńskiego wynika, że terminy „osoba moralna” i „osoba prawna” miały to samo znaczenie $^{21}$. Według A. Perlasci, treściowo były ono perfekcyjnie równoważne (perfettamente equivalenti) ${ }^{22}$. Należy przypomnieć, iż w kodyfikacji tej pojęcie „osoba moralna” było pojęciem dominującym. Nie odnosiło się ono wyłącznie do Kościoła katolickiego i Stolicy Apostolskiej, których osobowość znajdowała umocowanie w prawie Bożym (kan. $100 \S 1 \mathrm{KPK}$ ), ale również pod ten termin podpadały inne podmioty, które otrzymywały osobowość na mocy decyzji kompetentnego

1969, s. 24; A. Perlasca, Il concetto di bene ecclesiastico, Roma 1997, s. 241.

${ }^{18}$ Por. G. Michiels, Principia generalia de personis in Ecclesia, w: Commentario Libri II Codicis Iuris Canonici, Pairisiis - Tornaci - Roma 1955, s. 560 i 564.

${ }^{19}$ Por. F. Ferrara, Le persone giuridiche, Torino 1958, s. 29; Szerzej na ten teamt zob. G. Lo Castro, Personalità morale, dz. cyt., s. 66-67; A. Perlasca, Il concetto, dz. cyt., s. 241.

${ }^{20}$ S. Bueno Salinas, La noción de persona jurídica, dz. cyt., s. 131.

${ }^{21}$ A. Gautier, Le persone giuridiche, dz. cyt., s. 106; L. NAVARro, Persona e soggetti nel diritto della Chiesa. Temi di diritto della persona, Roma 2000, s. 153.

${ }^{22}$ A. Perlasca, Il concetto, dz. cyt., s. 232. 
autorytetu kościelnego (kan. $99 \mathrm{KPK})^{23}$. W zakres więc tego pojęcia wchodziło bardzo szerokie spektrum podmiotów, takich jak np. instytucje władzy rządzenia, zakony, stowarzyszenia, beneficja i wiele innych $^{24}$.

Badając zapisy kanonów Kodeksu pio - benedyktyńskim wspomniany już G. Lo Castro wykazał, iż wprowadzenia tego typu terminologii nie dało się jedynie, jak sugerowało większość komentatorów, wyjaśnić racjami stylistycznymi oraz systematyzacyjnymi ${ }^{25}$. Popierając to twierdzenie wskazywał on, że pewne nieścisłości występowały w takich regulacjach kodeksowych, jak: kan. 1499 § 2, $451 \S 1$, czy też kan. $1653 \S 3 \mathrm{KPK}^{26}$.

Ponadto w doktrynie zwracano uwagę, że odniesienie kategorii osobowości moralnej do Kościoła katolickiego i Stolicy Apostolskiej nie było ścisłe. Koncept bowiem tej osobowości był zróżnicowany w obszarach prawa kanonicznego, prawa publicznego Kościoła oraz prawa międzynarodowego ${ }^{27}$.

W ówczesnej doktrynie podkreślano, iż pojęcie „osoba moralna” nie jest koherentne $\mathrm{z}$ terminologią funkcjonującą w prawie świeckim. Stąd też w pracach kodyfikacyjnych nad drugim Kodeksem podjęto próbę zrewidowania podejścia do tego zagadnienia.

\section{Problem osoby moralnej w pracach nad rewizją Kodeksu z 1917 r.}

Kwestia znaczenia pojęcia „osoba moralna” była żywo dyskutowana $\mathrm{w}$ trakcie prac nad nową kodyfikacją. Prace nad tym niełatwym zagadnieniem opierały się na dwóch pryncypiach, z jednej strony miały one na celu ujednolicenie terminologii $\mathrm{w}$ systemie kanonicznym ${ }^{28}$ i zharmonizowanie jej z terminologią funkcjonującą w prawie świec-

${ }^{23}$ P. Lombardía, Lecciones, dz. cyt., s. 141.

${ }^{24}$ Tamże, s. 141-142.

${ }^{25}$ G. Lo CAstro, Personalità morale, dz. cyt., s. 42-43.

${ }^{26}$ Tamże.

${ }^{27}$ Por. B. Brown, The canonical juristic personality, Washington 1927, s. 90-91; S. Bueno Salinas, La noción de persona jurídica, dz. cyt., s. 150.

${ }^{28}$ S. Bueno Salinas, Persona moral, dz. cyt., s. 192. 
$\operatorname{kim}^{29}$, z drugiej zaś zmierzały do zupełnego porzucenia pojęcia „osoba moralna" 30 .

Rozpoczynając analizę procesu kodyfikacyjnego w interesującej nas kwestii na wstępie trzeba stwierdzić, że proces legislacyjny nie miał charakteru radykalnego, ale postępował w drodze ewolucyjnych zmian.

W czasie obrad II sesji „Zespołu Studiów nad zagadnieniami specjalnymi Księgi II" (Coetus studi de quaestionibus specialibus libri II), odbytej w dniach 9-12 grudnia 1967 r. postulowano wprowadzenie w nowej kodyfikacji następujących kategorii osób: osoba fizyczna, osoba prawna lub moralna oraz podmioty nieposiadające osobowości kanonicznej ${ }^{31}$. Należy jednak zauważyć, iż zwrot „osoba prawna lub moralna" nie pojawił się już w kolejnej propozycji zaprezentowanej na III sesji (5-9 listopada 1968 r.). W przedstawionym tekście bowiem pojawiła się kategoria „osoby kanonicznej (lub: prawnej)" ${ }^{{ }^{3} 2}$.

W trakcie prac, po przeprowadzeniu głosowania zdecydowano się na radykalny krok; skreślono pojęcie „osoba moralna”. Według H. Pree'a, na tą decyzję wpłynęła w głównej mierze przekonywująca argumentacja jednego z kosultorów utrzymującego, że termin ten jest niezrozumiały dla prawa świeckiego ${ }^{33}$. Stąd też uznano za bardziej odpowiednie operowanie bliższym prawu świeckiemu pojęciem osoby prawnej.

W „Communicationes” opublikowano zredagowane w 1973 r. wyjaśnienie Zespołu Studiów, dotyczące pojmowania osoby prawnej.

${ }^{29}$ A. Gautier, Le persone giuridiche, dz. cyt., s. 109.

${ }^{30}$ S. Bueno Salinas, Persona moral, dz. cyt., s. 192.

${ }^{31}$ Por. Communicationes 21(1989), s. 137-138. Opublikowany tekst brzmiał następująco: „In Ecclesia, praeter personas physicas, sunt etiam personae canonicae (vel iuridicae) [...]"; H. PrEE, Allgemeine Normen, w: Münsterischer Kommentar zum Codex Iuris Canonici, red. K. Lüdicke, t. 1, Essen 1985, ad. 113, n. 1.

${ }^{32}$ Communicationes 21(1989), s. 126 i 139; H. PreE, Allgemeine Normen, dz. cyt., ad. 113 , n. 1 .

${ }^{33}$ H. Pree, Allgemeine Normen, dz. cyt., ad. 113, n. 1. W swym komentarzu autor stwierdził: „Auf fruchtbaren Boden fiel die eines Konsultors, nur die Bezeichnung «persona iuridica» oder «canonica» sei klar, während «persona moralis» für das staatliche Recht weniger verständlich sei”. 
Otóż w tekście tym skonstatowano, że przez osoby te rozumie się podmioty praw i obowiązków różne od osób fizycznych, które są osobami w porządku moralnym, jako takie są uznane w porządku kanonicznym, a także osoby powołane do życia w tym systemie ${ }^{34}$.

W następstwie czego, w kan. 70 Schematu Księgi „De Populo Dei” z 1977 r., nie pojawiło się już pojęcie ,osoba moralna”. W projektowanej regulacji czytamy bowiem, że w Kościele, oprócz osób fizycznych istnieją także osoby prawne czyli kanoniczne, posiadające prawa i obowiązki zgodnie ze swą naturą ${ }^{35}$. W „Praenotanda” do Schematu Księgi II przyjęte ujęcie uzasadniono tym, że osobowość Kościoła katolickiego nie należy do porządku prawnego, ale do porządku moralnego ${ }^{36}$.

Zauważamy zatem, iż podczas prac kodyfikacyjnych zmierzano nie tylko do ujednolicenia terminologii, ale także do totalnego porzucenia terminu „osoba moralna”. W przekonaniu S. Bueno Salinasa, taki sposób podejścia wynikał z założenia w myśl którego, osobowość Kościoła katolickiego i Stolicy Apostolskiej się zakłada, podobnie jak zakłada się osobowość państwa. Według tego hiszpańskiego kanonisty, na taki sposób ujęcia wywarł poważny wpływ W. Onclin. W czasie prac bowiem Zespołu Studiów utrzymywał on, że kategoria „osoba moralna” należy do porządku socjologicznego; jest stworzona dla człowieka, bez interwencji autorytetu społecznego ${ }^{37}$. Krytycznie do tego poglądu odniósł się Bueno Salinas. Twierdził on, że argumentacja Onclina opierała się wyłącznie na zewnętrznych kryteriach socjologicznych;

${ }^{34}$ Communicationes 6(1974), s. 98: ,Vocantur illa obligationum et iurium subiecta quae non sunt personae physicae seu homines individui, et quidem sive in oridine morali sint personae, sed ordine canonico uti tales agnitae, sive in ordine canonico uti tales primo constitutae"; H. PreE, Allgemeine Normen, dz. cyt., ad. 113, n. 1.

${ }^{35}$ Communicationes 9(1977), s. 240: „Can. 70: In Ecclesia, praeter personas physicas, sunt etiam personae iuridice seu canonicae, subiecta scilicet in ordine canonico obligatiorum et iurium quae earum indoli congruunt".

${ }^{36}$ Tamże, s. 240-241: „Ecclesiae Catholicae personalitas non est ordinis iuridici, excepta quidem eius personalitate iuris gentium, sed est moralis, et ideo in Codiciis affirmari non debet [...]"; G. Lo Castro, Comento al can. 113 CIC, dz. cyt., s. 773; A. Perlasca, Il concetto, dz. cyt., s. 232.

${ }^{37}$ S. Bueno Salinas, Persona moral, dz. cyt., s. 192. 
abstrahował on natomiast od przesłanek eklezjologicznych, uwydatnianych w ówczesnej doktrynie ${ }^{38}$.

Zapis o osobowości moralnej Kościoła katolickiego i Stolicy Apostolskiej nie znalazł się także w Schema novissimum z 1982 r. ${ }^{39}$.

Komentując normy zawarte w tym dokumencie F. Coccopalmerio trafnie zauważył, iż z tego, że w trakcie prac kodyfikacyjnych opowiedziano się za kategorią osoby prawnej nie wynikało, że prawodawca nie znał kategorii osoby moralnej, czy też ją całkowicie porzuci ${ }^{40}$. Oceniając proponowane zapisy odniósł się on jednak do nich krytycznie podkreślając, iż zostały one przepełnione tendencjami pozytywistycznymi ${ }^{41}$.

Według S. Bueno Salinasa, przyjęte w Schemacie rozwiązanie wynikało z jednego z postulatów kodyfikacyjnych, zgodnie z którym należało zarzucić pojęcie „osoba moralna”, zastępując je terminem „osoba prawna"42. W tym kontekście powstaje jednak pytanie: dlaczego w projekcie tym zrezygnowano z kategorii osoba moralna? Odpowiadając na to pytanie Bueno Salinas zwrócił uwagę, iż tego typu sposób podejścia był następstwem pewnych założeń systemowych. Zakładano bowiem, że osoby prawne posiadają osobowość z prawa pozytywnego; osobowość Kościoła katolickiego i Stolicy Apostolskiej natomiast nie wynika z ludzkiego porządku prawnego, ale z porządku moralnego. Uważano, że tego typu osobowość się zakłada, podobnie jak zakłada się osobowość państwa ${ }^{43}$.

${ }^{38}$ Tamże: „La explicación de Onclin pecava excisivo extrinsecismo, pues auque no descartaba que paralelamente se deria una agrumentación de caracter eclesiológico (teológico) ponía excesivo acento en lo sociológico".

${ }^{39}$ Por. Pontificia Commissio Codici Iuris Canonici Recognoscendo, Schema novissimum iuxta placitum Patrum Commissionis emandatum atuqe Summo Pontifice praesentatum, Typis Polyglotis Vaticanis 1982; G. Lo CAStro, Comento al can. 113 CIC, dz. cyt., s. 773 .

${ }^{40}$ Por. F. Coccopalmerio, De persona iuridica iuxta Schema Codicis novi, Periodica 70(1981), s. 390: „Codex novus loquitur solummodo de persona iuridica. Hoc tamen non significat quod Codex novus personam moralem non cognoscat".

${ }^{41}$ Tamże, s. 399.

${ }^{42}$ S. Bueno Salinas, La noción de persona jurídica, dz. cyt., s. 196.

${ }^{43}$ Tamże, s. 193. 
Zdaniem S. Bueno Salinasa, redaktorzy Schematu w swym podejściu do tego zagadnienia wyszli z pozycji ideologicznych, opierając się w głównej mierze na teorii fikcji w której przyjmuje się, że tego typu osoby są powoływane do życia na mocy decyzji autorytetu kompetentnego ${ }^{44}$.

Z przeprowadzonych dotychczas analiz wynika, iż na skreślenie terminu „osoba moralna” zdecydowano się już w 1968 r.. Należy jednak spostrzec, że pojęcie to zostało przywrócone w ostatnim etapie prac; znalazło się ono bowiem w brzmieniu kan. $113 \S 1 \mathrm{KPK}^{45}$.

Wobec takiego zapisu normatywnego należałoby więc zapytać: jakie racje zadecydowały o ponownym wprowadzeniu terminu „osoba moralna" do kan. 113 § 1 KPK? Według wspomnianego już wielokrotnie S. Bueno Salinasa, takie ujęcie normatywne wynikało $\mathrm{z}$ faktu niepromulgowania „Lex Ecclesiae Fundamentalis”. Pierwotnie bowiem zakładano, że odniesienie do kategorii osoby moralnej pojawi się w tym akcie prawnym ${ }^{46}$.

\section{Pojęcie „osoba moralna” w Kodeksie z 1983 r.}

Z zaprezentowanych dotychczas rozważań wynika, że pomimo tendencji zmierzających do tego, aby w nowej kodyfikacji nie operować terminem „osoba moralna”, w ostatniej fazie prac kodyfikacyjnych zdecydowano o przywróceniu tego pojęcia. W kan. 113 § 1 KPK prawodawca postanowił bowiem: „Kościół katolicki i Stolica Apostolska są osobami moralnymi z samego ustanowienia Bożego".

\subsection{Status osobowości moralnej}

Komentatorzy zwracają uwagę, że zapis kan. 113 § 1 KPK jest identyczny z treścią kan. 100 § $1 \mathrm{KPK}$ z 1917 r. ${ }^{47}$. Należy jednak zauważyć, iż w nowym zbiorze termin ten nie ma już tak generalnego charakteru

${ }^{44}$ Tamże, s. 196.

${ }^{45}$ A. Gautier, Le persone giuridiche, dz. cyt., s. 110.

${ }^{46}$ S. Bueno Salinas, La noción de persona jurídica, dz. cyt., s. 198: „La disparición del horizonte legislativo de la tan distutida «Lex Ecclesiae Fundamentalis». En este sentido, parece que el legislador ha decidido no seguir adelante con el proyecto, lo cual le ha obligado a integrar en el nuovo C.I.C. buena parte del articulado Proyecto de tal Ley, que el Proyecto de C.I.C. suponía".

${ }^{47}$ P. Lombardía, Lecciones, dz. cyt., s. 143. 
jak w Kodeksie z 1917 r., ponieważ odnosi się wyłącznie do Kościoła katolickiego oraz Stolicy Apostolskiej ${ }^{48}$. Tym samym ustawodawca zdystansował się od rozwiązania występującego w Kodeksie pio - benedyktyńskiego, zgodnie z którym terminy „osoba moralna” i „osoba prawna" traktowano równoznacznie ${ }^{49}$. $\mathrm{Z}$ badań przeprowadzonych przez G. Lo Castro wynika, iż konsultorzy w czasie prac kodyfikacyjnych zmierzali do uwydatnienia zróżnicowania zachodzącego między pojęciami „osoba prawna” i ,osoba moralna”. Zgodnie z ich sugestia$\mathrm{mi}$, termin pierwszy miał być użyty w sensie generalnym; termin drugi natomiast traktowano w kategoriach wyjątku ${ }^{50}$. Zamierzenie to znalazło odzwierciedlenie w regulacjach Kodeksu z 1983 r. W obowiązującej kodyfikacji bowiem pojęciem dominującym stal się termin „osoba prawna" ${ }^{1}$; termin „osoba moralna” odniesiono wyłącznie do dwóch podmiotów, jakimi są Kościół katolicki i Stolica Apostolska (kan. 113 $\S 1 \mathrm{KPK})$.

\subsection{Specyfika podmiotowości Kościoła katolickiego i Stolicy Apostolskiej}

W myśl doktryny, zapis kan. $113 \S 1 \mathrm{KPK}$ ma charakter deklaratoryjny ${ }^{52}$. Osobowość moralna bowiem, o której traktuje ten kanon, jest uprzednia w odniesieniu do pozytywnej normy prawnej; jest ona niezależna od woli ludzkiej ${ }^{53}$. Jak zauważył G. Lo Castro, obecnie pod pojęcie osoby moralnej podpadają fenomeny naturalne oraz w jakiś sposób transcendentne względem porządku prawnego ${ }^{54}$. Ten typ osobowości w odniesieniu do Kościoła katolickiego jest oczywisty. Praw-

${ }^{48}$ A. Perlasca, Il concetto, dz. cyt., s. 232.

${ }^{49}$ G. Lo Castro, Comento al can. 113 CIC, dz. cyt., s. 775; H. Pree, Allgemeine Normen, dz. cyt., ad. 113, n. 4.

${ }^{50}$ G. Lo Castro, Comento al can. 113 CIC, dz. cyt., s. 772; A. Gautier, Le persone giuridiche, dz. cyt., s. 109.

${ }^{51}$ S. Bueno Salinas, La noción de persona jurídica, dz. cyt., s. 191; P. Lombardía, Lecciones, dz. cyt., s. 142-143.

${ }^{52}$ H. Pree, Allgemeine Normen, dz. cyt., ad. 113, n. 4.

${ }^{53}$ L. Navarro, Persona e soggetti, dz. cyt., s. 155.

${ }^{54}$ G. Lo Castro, Comento al can. 113 CIC, dz. cyt., s. 774. 
da ta została uwydatniona w sposób szczególny w Konstytucji Dogmatycznej o Kościele (KK 8) ${ }^{55}$. Stolica Apostolska natomiast posiada ją, gdyż jest reprezentantem prawnym Kościoła katolickiego ${ }^{56}$.

S. Bueno Salinas zastanawiając się nad specyfiką osobowości podmiotów wymienionych w kan. $113 \S 1$ KPK stwierdził, iż nie wynika ona wyłącznie ze źródła ich pochodzenia jakim w tym wypadku jest prawo Boże, lecz również z faktu, że hierarchicznie Kościół katolicki i Stolica Apostolska mają charakter wyższy względem innych podmiotów ${ }^{57}$. W doktrynie bowiem utrzymuje się, iż w kanonicznym porządku prawnym osobami moralnymi są nie tylko te wskazane w kan. $113 \S 1$ KPK, ale również inne podmioty, takie jak np. Kolegium Biskupów ${ }^{58}$, czy też partykularne ${ }^{59}$. Ostatnie z wymienionych nie są jednak określane mianem osób moralnych ze względu na to, iż nie posiadają one niezależności właściwej Kościołowi katolickiemu i Stolicy Apostolskiej, a także są im hierarchicznie podporządkowane ${ }^{60}$. Według kanonistów, status Kościoła katolickiego i Stolicy Apostolskiej ma charakter ponad prawny (entes supra-jurídicos) ${ }^{61}$.

W literaturze wymienia się jeszcze inny powód ujęcia występującego w kan. $113 \S 1$ KPK. Otóż podkreśla się, iż wynika ono z racji apologetycznych. Według S. Bueno Salinasa, poprzez wprowadzenie tego typu kategorii pojęciowej ustawodawca broni niezależności podmiotów wymienionych w tym kanonie od innych autorytetów tego Świata ${ }^{62}$. Odnosząc się do tej kwestii R. Sobański wskazywał, iż już w kodyfikacji pio - benedyktyńskiej zapis kan. 100 § 1 KPK posiadał

${ }^{55}$ Por. V. De Paolis, A. D’Auria, Le norme generali di Diritto Canonico. Commento al Codice di Diritto Canonico, Roma 2008, s. 312.

${ }^{56}$ Por. S. Bueno Salinas, Persona jurídica, w: Diccionario general de Derecho Canónico, red. J. Otaduy, A. Viana, J. Sedano, t. 6, Pamplona 2012, s. 181.

${ }^{57}$ S. Bueno Salinas, Persona moral, dz. cyt., s. 193: „En el ambito eclesiológico interno, la personalidad moral de la iglesia universal coresponde no solamente al origen divino de su existentia, sino también a su carácter superior".

${ }^{58}$ H. Pree, Allgemeine Normen, dz. cyt., ad. 113, n. 4.

${ }^{59}$ L. Navarro, Persona e soggetti, dz. cyt., s. 155.

${ }^{60}$ S. Bueno Salinas, Persona moral, dz. cyt., s. 193.

${ }^{61}$ S. Bueno Salinas, La noción de persona jurídica, dz. cyt., s. 195.

${ }^{62}$ S. Bueno Salinas, Persona moral, dz. cyt., s. 193. 
charakter apologetyczny. W myśl jego opinii, ujęcie to miało zapewnić Kościołowi odpowiedni status publiczno - prawny. Tym sposobem prawodawca kościelny przeciwstawił się przedkodeksowym poglądom niektórych autorów twierdzących, że Kościół katolicki uzyskał dopiero osobowość prawną w następstwie edyktu mediolańskiego, wydanego w 313 r. (F. Schulte). Trafnie zauważył on, że przyjęcie tego typu stanowiska konsekwentnie prowadziło do wniosku, iż osobowość prawna Kościoła katolickiego jest zależna od prawa cywilnego. W tej optyce, osobowość prawna Kościoła wchodziłaby w obszar prawa wyznaniowego, a nie prawa kanonicznego ${ }^{63}$. Ustawodawca kościelny przeciwstawiając się tego typu tendencjom, zdaniem R. Sobańskiego, wprowadził kan. $100 \S 1$ KPK z 1917 r. stanowiąc, że Kościół posiada osobowość prawną nie z ustanowienia ludzkiego, ale z prawa Bożego ${ }^{64}$. Według H. Pree’a, właściwym punktem odniesienia w interpretacji kan. $113 \S 1$ KPK jest eklezjologia Soboru Watykańskiego II. Popierając to twierdzenie skonstatował on, iż obecnie nie można wywodzić na zasadzie analogii osobowości Kościoła katolickiego i Stolicy Apostolskiej z suwerenności państwa, lecz z Boskiego pochodzenia tych podmiotów ${ }^{65}$.

Zdaniem S. Bueno Salinasa, deklaracja tego typu osobowości znajduje wyraz w sferze publicznej, ponieważ wiąże się ona z podmiotowością Kościoła katolickiego na arenie międzynarodowej. Jej uznanie nie wynika wyłącznie z racji historycznych, ale z racji o wiele poważniejszych, ponieważ osobowość ta wypływa z prawa Bożego ${ }^{66}$.

Skutkiem wewnątrzkościelnym natomiast tej osobowości z jednej strony jest wyposażenie Kościoła we władzę rządzenia, z drugiej zaś nadanie osobowości innym podmiotom w obszarze wewnątrzkościelnym $^{67}$.

\footnotetext{
${ }^{63}$ Por. R. SobańsKi, Kościół jako podmiot prawa, Warszawa 1983, s. 69-70.

${ }^{64}$ Tamże.

${ }^{65}$ H. Pree, Allgemeine Normen, dz. cyt., ad. 113, n. 4.

${ }^{66}$ S. Bueno Salinas, Persona moral, dz. cyt., s. 193.

${ }^{67}$ Por. R. Sobański, Komentarz do kan. 113 KPK, w: J. Krukowski, R. Sobański, Komentarz do Kodeksu Prawa Kanonicznego, t. 1, Poznań 2003, s. 188.
} 


\section{Zakończenie}

Z przeprowadzonych analiz wynika, iż znaczenie pojęcia „osoba moralna" w pierwszej kodyfikacji było równoznaczne z pojęciem osoba „osoba prawna”. Przy czym w systemie tym dominowała kategoria osoby moralnej. Komentatorzy Kodeksu z 1917 r. zwracali jednak uwagę, iż terminologia funkcjonująca $\mathrm{w}$ tym zbiorze nie przystawała do tej, która funkcjonowała w prawie świeckim. Stąd też w trakcie prac kodyfikacyjnych z jednej strony zamierzano do unifikacji terminologii $\mathrm{w}$ tej materii, $\mathrm{z}$ drugiej zaś do uwydatnienia zróżnicowania zachodzącego między pojęciami „osoba moralna” i „osoba prawna”. Na przełomie lat 60. i 70. zdecydowano się na wycofanie nazwy „osoba moralna" z obiegu normatywnego, popierając podjętą decyzję tym, że osobowość Kościoła katolickiego i Stolicy Apostolskiej jest uprzednia w odniesieniu do innych podmiotów występujących w kanonicznym porządku prawnym. W ostatniej fazie prac zdecydowano się jednak na przywrócenie tego pojęcia $\mathrm{w}$ nowej kodyfikacji. O takim kroku przesądziło w głównej mierze niepromulgowanie „Lex Ecclsiae Fundamentalis"; pierwotnie bowiem w tym akcie prawnym zamierzano się odnieść do kwestii osobowości moralnej.

Trzeba podkreślić, iż w Kodeksie z 1983 r. zakres terminu „osoba moralna" jest ograniczony. Odnosi się on wyłącznie do Kościoła katolickiego i Stolicy Apostolskiej. W publikacji tej wykazano, iż obecnie pojęcie to znajduje umocowanie nie tylko w przekonaniu, że źródłem pochodzenia tych podmiotów jest prawo Boże, lecz także w założeniu, iż podmioty te hierarchicznie mają charakter wyższy od innych podmiotów funkcjonujących w kanonicznym porządku prawnym. W doktrynie także wskazuje się, iż deklaracja zawarta w kan. 113 § $1 \mathrm{KPK}$ zapewnia Kościołowi katolickiemu i Stolicy Apostolskiej odpowiedni status publiczno - prawny, ponieważ wskutek wprowadzenia tego typu deklaracji prawodawca kościelny pragnie chronić niezależność wymienionych w normie podmiotów względem władzy świeckiej. W myśl doktryny, dyspozycja kan. $113 \S 1$ KPK ma charakter postulatywny w odniesieniu do władzy świeckiej. Ustawodawca kościelny 
bowiem dąży do zapewnienia suwerenności Kościołowi w otaczającej go rzeczywistości świeckiej ${ }^{68}$.

Wreszcie należy dodać, iż tego typu podmiotowość znajduje wyraz nie tylko w sferze zewnętrznej, ale również w sferze wewnątrzkościelnej. Skutkiem wewnątrz kościelnym z jednej strony jest wyposażenie Kościoła we władzę rządzenia, z drugiej zaś nadanie osobowości innym podmiotom w obszarze wewnątrzkościelnym.

Należy zgodzić się z opinią wyrażoną przez R. Sobańskiego, który trafnie spostrzegł, iż polskie tłumaczenie kan. $113 \S 1$ KPK jest niepoprawne. Przekonywał on, iż Kościół katolicki i Stolica Apostolska nie są osobami moralnymi, lecz osobami o charakterze moralnym ${ }^{69}$.

W obowiązującej kodyfikacji, w przeciwieństwie do poprzedniej, dominującą kategorią jest osoba prawna. Prawodawca odnosi ją do rzeczywistości stworzonej przez prawo. Dookreślenie „prawne” bowiem wskazuje, iż pewne podmioty posiadają osobowość na mocy prawa.

\section{The evolution of the term „moral person” in the canonical legal order}

The author of the presented article focused his attention on the question of the evolution of the term "moral person" in the canonical legal order. The analyses he carried out show that in the Code of 1917 the term "moral person" was dominant and equivalent to the term "juridical person". However, the commentators of the Code of 1917 pointed out that the notion did not suit other notions functioning in the secular law. Therefore, present codification uses the term "juridical person" while the term "moral person" refers only to the Catholic Church and the Apostolic See (can. $113 \S 1$ ).

In his considerations, the author proved that the notion "moral person" originates from the conviction that the source of all subjects mentioned in can. $113 \S 1$ is Divine law but also from the belief that hierarchically these subjects are superior to other subjects functioning in the canonical legal order.

The author believes that the regulation included in can. $113 \S 1$ is of apologetic nature. By introducing this kind of declaration, the ecclesiastical legislator intends to protect the independence of the Catholic Church and the Apostolic See from the secular law.

\footnotetext{
${ }^{68}$ Tamże.

${ }^{69}$ Tamże.
} 
This type of subjectivity is also reflected in the inter-ecclesiastical field. On the one hand, it equips the Church with the ruling power, but it also gives other subjects a legal status in the inter-ecclesiastical area. 